\title{
Mediation's role solving conflicts in corrupted judiciary systems
}

\author{
Arsiola Dyrmishi \\ Lawyer and mediator \\ PhD Candidate in Public Law \\ arsioladyrmishi@gmail.com
}

DOI:10.5901/mjss.2014.v5n22p12

\begin{abstract}
Mediation in conflict resolution constitutes a new trend in restorative justice. Mediator's procedures are "sanctioned" since Antiquity and later in the years 1999, 2003 and 2011. However, only after the first licensing of mediators and the Creation of National Chamber of Mediators in Albania we can seriously talk about the beginnings of the institutionalization of mediation. Why Albanian State and USAID and JUST program are investing in mediation conflict-resolutions? The main reason is because Albanian Judiciary System is estimated, perceived as extremely corrupted. Mediation is extremely important in corrupted judiciary systems as arrives to resolve conflicts satisfactorily for conflicting parties, it takes less time and less financial costs. It looks like mediation solving conflicts gives to the conflicting parties what the corruption denies. This paper will analyze the role of mediators in the resolution of conflicts, the need to bring qualitative changes in the practices of conflict resolution, the big challenge of establishing trust and everything connected with a biased process. The paper will be described by some questions and above all the question mark is if it possible to extend the mediation procedures in all conflict resolution? What is public impact of mediation? Is it possible to have corrupted mediation as corrupted as judiciary system? What is the solution if it happens? Some findings and conclusion will be the last session of the paper bringing us a clear picture of what the mediation should be.
\end{abstract}

Keywords: Corruption; role, mediator; solving conflicts, judiciary system

\section{Introduction}

Judiciary system is part of tripartite system as described firstly by Baron de Montesquieu. Montesquieu goes further when he said that "the independence of the judiciary has to be real, and not apparent merely". "The judiciary was generally seen as the most important of powers, independent and unchecked", and also was considered dangerous.(Montesquieu, Charles-Louie. The Spirit of Laws).More and more governments in the world are reforming judiciary system trying to establish an effective, professional and impartial judiciary system. Apart institutional commitment, success or not of judiciary reform agenda, it remains one of the most controversial powers, more so in judicial systems that are perceived by the public as corrupted. Firstly it is important to deal with the concept used in this paper. What is corruption and what is mediation or mediator? As we all know there is not a universally recognized definition of corruption, many practitioners in the field use Transparency International's definition, or "the abuse of entrusted power for private gain." In international law, a person commits the criminal act of corruption when he or she "promises, offers, or gives" undue benefits to a public official "in order that the public official act or refrain from acting in the exercise of his or her official duties." If a public official solicits or accepts such an undue advantage, that also counts as corruption.(United States Institute of Peace, Study Guide Series on Peace and conflict). The second key concept of this research paper is mediation. Sometimes it is used mediation or ADR. It is ADR the same concept as mediation? The doctrine says no because using the concept ADR we mean processes that may be used within or outside courts and tribunals to resolve disputes, where the processes do not involve traditional litigation processes. The term describes processes that are non-adjudicatory, as well as adjudicatory, that may produce binding or non-binding decisions and includes processes described as mediation, evaluation, case appraisal and arbitration. It is understood that ADR is a wider concept as mediation and it refers all alternative dispute resolutions.

According to legal dictionary mediation is "the attempt to settle a legal dispute through active participation of a third party (mediator) whoworks to find points of agreement and make those in conflict agree on a fair result. Mediation differs from arbitration which the third party (arbitrator) acts much like a judge but in an out of court less formal setting but does actively 
participate in the discussion. Mediation has become very common in trying to resolve domestic relations disputes(divorce, child custody, visitation), and is often ordered by the judge in such cases. Mediation also has become more frequent in contracts and civil damages cases. There are professional mediators, or lawyers who do some mediation for substantial fees, but the financial cost is less than fighting the matter out in the court and may achieve early settlement and an end to anxiety.( http://legal-dictionary.thefreedictionary.com/Mediation)

However, mediation does not always result in a settlement. We used this definition to introduce in the paper and in the linkage between mediation-corruption and judiciary system.

\section{Background of the research}

The Albanian term mediation first surfaced in the anquity. This does not mean that mediation as a mode of dispute resolution was hither to unknown in the Albania. Mediation, as a process of third party assisted bargaining, had existed for several centuries, performed as assemblies, presbyteries, blood feuds reconciliation commissions and social courts. These methods of dispute resolution were commonly practiced as a side-activity by judges, mayors, or yet other functionaries, using their intuition, experience of life, or mere authority. The "mediation" was regulated by albanian Canon(Canon of Lekë Dukagjini, article 668, 682), different laws (Law no. 83, dated 23. 05. 1928 "On the civil administration of the Albanian Kingdom", or Law No. 4406, dated 24. 06. 1968 "On the organization of the judiciary system" ). In the customary law mediation was part of judiciary system, in so called social court, at that time part of judiciary system. The social court (including village court or neighborhood court) should take all appropriate steps to resolve disputes by reconciliation (Mandro, 2008). Here lies an essential difference with the modern mediation in Albania. There are three laws, the first one of the years 1999, the second one the law of 2003 and the last one of the year 2011. The last legal framework is in full accordance with the international legal framework regarding mediation, the directives of European Union and the European Code Ethics of Mediators. It is possible to discuss about modern concept of mediation referring the last legal framework. According to the law of 2011 mediation and all legal acts regulating mediation process, mediation is as an extra judicial independent activity, undertaken voluntarily by parties in civil, commercial, labor and family disputes, and in certain penal cases. The current Mediation Law, which entered in force on April 9, 2011, assigns the Ministry of Justice the responsibility of creating and maintaining the Register of Mediators, and establishes the National Chamber of Mediators. The law obligates judges to invite parties in relevant court cases to participate in mediation, thus providing an important tool for faster decisions and increase transparency in the courts. The law sanctioned criteria for mediators and only after being licensed from the License Commission in the Ministry of Justice and after registered in Mediator Register a person or a mediation office could mediate cases. Actually in Albania it is established National Chamber of Mediators (Since July 7th 2013) and actually there are 54 (Fifty four) mediators and two mediators office or foundations. (Ministry of Justice, June 2014) . However before the Law of 2011 entered in force there are some important projects of JuST and USAID in Albania with four district courts since February 2009. USAID JuST a very important partner and counterpart is a five-year project to increase court transparency, fairness and efficiency; bolster watchdog and anticorruption roles of civil society organizations and media; and strengthen the legal profession and legal education in Albania. Thanks to this project, regarding its benefits in the mediation the process is a successful story and the statistical data show that the Albanian people are supporting the mediation bringing the cases before the mediators, avoiding courts. Describing the background of the research only dealing with the mediation as a new alternative of resolving disputes it is not enough and it doesn't explain the linkage between the mediation, corruption and the judiciary system. Albanian judiciary system is perceived as most corrupted. It is widely accepted and confirmed from all researchers, Albanian or not that judiciary system in Albania is corrupted. The last report (2013) of U. S Department of State concluded that corruption is one of the main violators of human rights in Albania and it continues to be a serious concern. More regarding the corruption, it is the interview of chef of Euralius Mr. Joaquin Urias. He said there are not statistical data and concrete numbers of corruption in Albania because the corruption is not punished (an other grave problem) but the whole system of justice is corrupted. According to him corruption has become systemic, being thus the rule and not the exception(See more http://www. infocip. org/en/?p=1199). It is possible giving justice in a corrupted judiciary system ? Head of High Court of Republic of Albania, Judge Xhezair Zaganjori in the conference "Rule of Law and Reforms in Albania" co-organized in Brussels by foundation "Hanns Seidel, declares "There is no court when the judge declares the verdict based on political influence or corruption because there is no impartial and efficiency, two fundamental values of judiciary system. " Corruption is structurally rooted, and officials often ignore or bend laws and policies, report false information and neglect the welfare of the population under their constituency (Lieberthal, 2004). Even though bureaucratic and commercial corruption is highly undesirable, judicial corruption is far more problematic. Courts are legitimately supposed to realize the law's corrective justice with reasonable competence. A clean judiciary could not fundamentally curb governance problems; but a corrupt judiciary will not only be irresponsive but also intensify rising complications. Corrupt judges placed on the frontiers of exercising legal power are largely 
unfit to give fair adjudication, because their own objectives often go beyond the proper application of the law. Their actions may be motivated by self-interest and subjected to interventions by sources of corruption. (Eric Chi, 2008). A justice system, and the processes located within it, ought to deliver justice. (Welsh, Vol. 5:117). While you are reading this the first question you have is justice delivered equally for all? Even the principle of equality is old as humankind it is not applied perfectly . The corruption affects the public services, and so on the corruption in judiciary system affects equal delivering of the justice, and impacts mostly the poor. Courts possess the decision, which is binding on the parties to the judicial process to be implemented and executed but let's think for a moment ... a judicial decision which one of the parties does not believe that it is in accordance with the law not only does not solve the conflict but also generates a new conflict that will accompany the execution phase of decision. We can not completely avoid conflicts but can find the best solution for them. Michael Barker said in his article in web page State of Nature "Conflict is not the enemy, but instead is the means of promoting justice. Unresolved conflicts that are "resolved" without adequate justice (via ADR and the like) are ultimately the enemy of all humankind, as they help institutionalize inequality. "According to Barker and the others, mediation is estimated as A. D. R ( abbreviation of alternate dispute resolution) and now on it is estimated as Adequate Dispute Resolution regarding greater flexibility, costs below those of traditional litigation, and speedy resolution of disputes, among other perceived advantages. In this paper observing role of mediation in corrupted judiciary system it is important to emphasize advantages of mediation in dispute solving. According to Laura Nader in her review of Jerold Auerbach's book Justice Without Law? (Oxford University Press, 1983), Laura Nader recounts how Auerbach wrote that prior to the Civil War, "alternative dispute settlement had expressed an ideology of community justice. Thereafter, "Nader continues "according to Auerbach, it became an external instrument of social control and a way of increasing judicial efficiency. "

After introducing shortly the background of the paper, the chronological presentation of mediation in Albania, on arrival in the contemporary concept of mediation, as it is taking place recently in one of the most judiciary corrupted system in Europe and not only in the second session it will be discussed about methods used in this research paper, an analytical discussion will be about the linkage between them trying to point out some conclusions and recommendations about the future of mediation in Albania.

\section{Method}

\section{Mixed methods of research}

The author decided to use mixed methods research because of the advantage of mixed methods. It is argued that mixed research methods have several advantages. Mixed methods provide guidance for others in connection with what researchers are intended to do or have done (Creswell 2003 ). Mediation (contemporary concept of it in Albania) is a new process so there are not a lot of statistical data and it is much more important providing some conclusion on it, trying to go beyond of the barriers.

\section{Materials}

Quantitative data of cases of conflicts resolute by mediation. Data are provided by Ministry of Justice in Albania, National Chamber of Mediators, Foundation of Solving Conflicts and Reconciliation of Disputes and data of 4 (four) Court Districts in Albania where it is implemented a pilot project of mediation (Korca District Court, Durres District Court, Saranda District Court and Gjirokastra District Court as well ) Statistical data are provided as well by JuST and USAID, two very important counter-parts of this project.

There are some qualitative researchers on mediation in Albania, especially in penal process. We will use some of their finding just to elaborate a common sense of mediation and how it is perceived by the scholars.

\section{Results}

The main aim of this study was to evaluate role of mediators in solving conflicts in corrupted judiciary system. For this purpose, firstly it is important to clarify if presence of mediation affects or change something in corrupted judiciary system. Secondly it is as much important to distinguish the voluntary choice of parties in a mediation process. The choice is due to the negative effects of corruption or because of bureaucracy, formal procedures and inherent complexity of having a trial process.

\section{Findings}


Using secondary data of researchers about mediation and the reason why the parties choose mediation , the reasons are as below:

-Through mediation, the parties reduce the expenses

-Reduce stress of court proceedings

-Reduce the emotional toll of conflict.

-In divorce mediation and other family mediations (such as elder mediation, estate planning mediation, and family business mediation), the participants benefit greatly by preserving the possibility of ongoing relationships in the future, if they so choose.

-It gives substantial control to the parties, rather than a judge or a court

-Mediation provides privacy and confidentiality, while the trial is public. This is extremely important in the disputes relating so called "private life .

-Disputes are solved in a creative way.

-The mediation solve the conflict while the Court Decision is about the case.

Using secondary data we listed the reason and now it's time to discuss what is not offered in trial process because of the corruption.

The first reason is reducing expenses. Expenses, financial costs are the most notable effect of corruption. Bringing the case before the court where the judges are corrupted costs more. Mediation costs less than a court trial process. Costs refer to official fee to present the case before the court, acquisition of the documents, fee of services of attorney and the costs of corruption). Choosing the mediation you choose to pay only fee of services of mediators. The fees are approved by National Chamber of Mediators .

The second reason of the parties is reducing stress of court proceedings. The court proceedings are stressful even for the lawyers and other professionals so it is easy to understand how stressful they are for parties in the conflict for who the court proceedings are not familiar. We will not stop at this reason and other reasons that are not because of the corruption but because of the organization of judiciary system.

An other reason, strongly related to the corruption is because the parties are not confident to judicial system. According to them the verdict courts are given affected of corruption or political influence. The verdict's court often is partial. The international statistical show that more and more people are losing faith in judicial system. The U. S State Department, year 2013, referring Albania regarding the corruption address:" State institutions that treat the fight against corruption remain vulnerable to political pressure and influence, while the fight against corruption in the judiciary has made limited progress ". The corruption in judiciary system is a double problem cause it means not only not delivering justice but as well not punishing it. In a democracy based on the rule of law, the role of the judiciary, as an independent and equal branch of government, is to protect human rights and civil liberties by ensuring the right to a fair trial by a competent and impartial tribunal. All citizens expect equal access to the courts and equal treatment by the investigative bodies, prosecutorial authorities, and the courts, regardless of their position in society. Yet, under most corrupt judicial systems, the powerful and wealthy can escape prosecution and conviction, while large segments of society are excluded from their rightful access to fair and effective judicial services. ( Pepys, 2003). Concluding the findings corrupted judiciary system affect:

-Faith of public in judiciary system

-More and more expenses

-Stressful court proceedings

-Violates equality before the law and access in the justice

For all above reasons more and more people are choosing mediation. According to American statistical there was a similar view expressed among the sixty disputants involved in in-depth interviews. Many expressed the view that they would wish to avoid the courts in the future, and ADR as well as lawyer-to-lawyer discussion were pathways to do so.

The mediation exist, the legal framework as well but are the parties informed about it?

The mediation is more popular and known among professionals of the field than in the public. People missed the important information that agreement of a mediation process has the legal effect of a court verdict. The National Chamber of 
Mediators, judges, police officers, officials of probation services and mediators itself should inform parties for this advantageous alternative of dispute solving.

According to Ministry of Justice of the Republic of Albania for the years 2013-2014 the number of conflicts(disagreement) solved through mediation are shown as below: The total numbers of cases presented to solve through mediation is 167 .

From that : 90 cases belong to Korca Court District , 35 cases belong to Durres Court District , 43 cases belong to Saranda Court District and only five of them belong to Gjirokastra Court District. $75 \%$ of the cases are solved through mediation . (Speech of Minister of Justice of the Republic of Albania, Mr, Nasip Naco in the meeting "Mediation , a new alternative of solving conflicts in Albania", organized by National Chamber of Mediation, in the attention of Ministry of Justice ")

\section{Discussion}

In the discussion session of this research paper I would like to pay attention to some debated question.

After proved the linkage between corruption in judiciary system and positive effects of mediation in fighting corruption, which is the guarantee that the theory that mediation fight corruption in judiciary system is true and can be implemented successfully?

There are enormous theories of combating corruption in judiciary system. They vary from new selection systems, higher salaries, guaranteed tenure, ethical training, courtroom automation and improved monitoring and discipline. They have different rates of success, but none of them could vanish corruption. Going further UN Office on Drugs and Crime (UNODC) said it became evident, however, that judicial corruption could only be addressed effectively as part of a broader, systematic and sustainable approach aimed at enhancing both the integrity and the capacity of the judiciary and the courts. ( Hammergren, 2003). Why we should believe that mediation could seriously fight corruption?

The mediation's role fighting corruption in the judicial system it is mainly because of removing the monopoly-power of judicial system to resolve conflicts. An other reason is because judges and other law enforcement bodies of the judiciary in Albania are threatened due to the refusal of public regarding judicial system. This refusal is expressed through strongly support of mediation. The other theories of combating corruption have been focused inside the system. It will be interesting to see how an other structure "outside" of courts will affect the court, and the last but not least is that mediation will face the judiciary system with new standards, widely approved.

An other debated question is what kind of justice is delivered by the mediation process? We will introduce to the question shortly presenting the colonist view towards juries. They considered juries as as the "guardians of local community values against outsider judges appointed by the royal governor" and "as bulwarks of integrity against corrupt public officials. (Welsh, 2004) Are the mediators replacing juries, can we consider them guardians of local community values? Is mediation agreement delivering social justice, deeply wanted by community ? ? Mediation is part of a real and genuine reform in judiciary system . In every time, but mostly now we need to highlight the need of a professional, eficent and impartial judiciary system. Other way there is no sense discussing about the rule of law or human rights protection. Starting from the point of view of judge Wayne Brazil who has urged that the process "democratized our institution [the courts] in potentially profound ways because mediation permitted, in fact actively encouraged, the parties to decide for themselves which values were most important to them, then to use ADR to pursue those values. ", in my opinion mediation it is not only alternative dispute resolution, even adequate dispute resolution but is a way tackling corruption. It represent a new standard of justice, community justice, not an abstract concept of justice as it sanctioned in legal instruments, but a kind of justice coming from the parties including in conflict. Justice coming the parties is accepted, is not controversial and the parties have faith in it and believe in real equality. In that sense, mediation is what justice is missed and what people strongly wish to find in judiciary system. Let's go back in the very beginnings of the contemporary mediation movements, in the late years 1970s and the early 1980s when the movement was inspired by the principles of democracy. (Welsh, 2004)

Albania missed time to reform judiciary system and make this system more efficient, transparent and impartial. Mediation is part of reform agenda and it is time to play much more significant role in delivering the missed justice.

This research paper outlined the linkage between corruption in judicial system and mediation. It is accepted the positive effects of mediation in fighting corruption in judicial system but policy makers should keep in my mind that it is one of the ways and it should be combined to the others to be real and successful. 


\section{References}

Canaj, E\&Aliu, E (2012 ) Commercial Mediation as a contemporary option to conflict resolution. Economicus 9. pp 207219

De Roo, A\& Jagtenberg, R( ) Mediation in the Netherlands, past-present-future . pp 127-146

Doyle, M\&Bondy, V(2011). Mediation in Judicial Review. The public law project. pp 1-71

Haley, J (1996). Court mediation and the search for justice through law. 74 Wash U. L. Q 47 . pp48-82

Hammergren, L (2003). Lessons learned about fighting corruption. pp 138-164

Hedeen, T\&Coy, P(2000) Community Mediation And The Court System: The Ties That Bind. Mediation Quarterly, Volume 17, Number

Ip. E. C(2008). Judicial corruption and its threats to National Governance in China, JOAAG, Vol 3. No. 1 pp 80-89

RrCe, $\mathrm{P}(1979)$. Mediation and arbitration as a civil alternative to the criminal justice system, an overview and legal analysis. The American University Law Review , Vol 29:17. pp 18-81

Pepys, M(2003). Corruption and the justice sector. Management systems international. pp 1-21

Welsh, N (2004). The place of court-connected mediation in a democratic justice system. pp 117-144

Web pages:

http://www. dreitesia. gov. al/al/dokumente/komisioni-i-licensimit-te-ndermjetesve

http://www. usaid. gov/news-information/press-releases/usaid-supports-court-mediation-albania

Tables

Table 1. Mediation versus Court

\section{COMPONENTS}

Time

(Faster)

Party control

Human Rights

Simpler

Confidentially

\section{MEDIATION}

Mediation cases take an average of two weeks to a few months for conclusive resolution

Substantial party control.

Respected and equal for everyone

It takes less time, it is less stressful, it is not as formal as court proceedings.Disputes are solved in a creative way

The parties have full faith in the mediator.They choose him or her voluntary. They believe he/she is able to solve their disputes. The mediation

\section{COURTS}

Can take at least a year and half on the average to resolve, not to talk about possible appellate processes in the higher Courts. Further, time for execution of the judgment could take a further couple of years sometimes.

There is no substantial party control.

Fair trial process and other human rights sanctioned are violated in corrupted judiciary system

Court proceedings are formal, timetable decided from the administrative staff or the judge .Takes more time and it is more stressful.

The judge or the panel of judge are determined by lottery. The parties have their opinion about his/their impartiality.Sometimes they do not 
Voluntary

Access

Effective

Justice agreement is signed by the both parties and they are winer-winer

Social justice

close to the citizens - an essential factor of social cohesion

believe he/she/they are able. They are doubtful about selection criteria of the judges.Undoubtfully one of the parties, mainly loser, or sometimes both of them loser and winer believe that the verdict court is not in accordance with the law.

Parties decide about the mediator.

Parties decide if they want to solve the dispute through mediation

The parties do not decide about the judges or the panel of judges.

If one the parties bring the case before the court, it is not important the will of the other party.An absence court decision is always possible.

The poor and the other discriminated target group of the society could access the mediation process.

In a corrupted judiciary system to the poor and discriminated is denied the access in the judicial system

It resolve the disputes, conflicts.

After the mediaton process both parties have a common future

It gives a decision court about the case.The decision court could generate a new conflict between parties.

Conventional, abstract justice

In the best way it is in accordance with the legal provisions, abstract articles.

Table 2.Cases that should try to be resolved by mediation before going in the Court (According to Albanian law)

Law No 10385 dated 24.2.2011 "For the mediation solving disputes in the Republic of Albania".

Penal Cases
Sanctioned in the article 59 and 284 of Criminal Procedure Code for criminal cases category, such as beating, serious injury by negligence, injury due to negligence, violation of domicile, defamation and other cases, it results that the injured, (the victim) has the right to directly petition the court the criminal case and to take part in the hearing as a party, to prove the charge and to obtain compensation.

Also, under Article 284a of the Criminal Procedure Code are defined cases of criminal prosecution conflicts starts from prosecution or judicial police only based on the complaint of the victim, the injured party against the defendant, who may withdraw the appeal by addressing mediation stage of the proceedings. These cases are injury 
due to negligence, manslaughter, insult and slander because of duty, etc..

Family Cases

Divorce, child custody, parental obligations, and all the cases of the high interest of child

Civil Cases

Civil, labour and commercial cases

Table 3.How mediation reduce corruption in judicial system?

Removing monopolistic power of judicial system in resolving conflicts

Establishing an "outside" court structure

It is a clear example of refusal of corruption in judicial system

It represent new standarts of justice, which should be part of conventional justice given in trial process

New standarts of professional conduct 